\title{
Micro Credit is a Tool for Women Entrepreneurship Development
}

\author{
Rathiranee Yogendrarajah ${ }^{1}$, Semasinghe S.D ${ }^{2}$ \\ 1. Department of Financial Management, Univerisity of Jaffna. \\ 2. Department of Commerce \& Financial Management, Univeristy of Kelaniya.
}

Received: May 28, 2015 / Accepted: June 25, 2015 / Published: September 25, 2015.

\begin{abstract}
As a result of 30 years of an internal armed conflict, women and children not only lost male relatives in struggle, but comprised of the displaced. Most of the households in Sri Lanka are now headed exclusively by women. The micro finance institutions help the poor people in effective ways in order to generate income to enhance their standard of living in the rural areas. This study focuses on women entrepreneurship development through micro credit programme under post war development in Jaffna District selecting four rural areas which are Kopay, Chavakachcheri, Varani and Kodikamam. The main objective of this study is to identify the linkage with micro credit programmes and entrepreneurship development. Further it has an objective to identify the impact of micro credit on entrepreneurship development. The information has been gathered by primary data which has been distributed through the close ended questionnaire to the rural women in the above selected areas and seventy seven (77) responded out of 100. The relation between the micro credit programmes and women entrepreneurship development is examined using Statistical Package for Social Sciences (SPSS). It is concluded that the Entrepreneurship development has a significant relationship $(\mathrm{p}<0.05)$ with the microcredit programme and its impact on entrepreneurship development is crucial. It is suggested that the microcredit facilities are essential in women entrepreneurship development under post war development.
\end{abstract}

Key words: Entrepreneurship Development, Micro credit, Post war development and Women Empowerment.

\section{Introduction}

Women still face numerous challenges in accessing education and health services, as well as economic development. The women empowerment is a critical element in the world and special attention is given to the women in the nations. Women Empowerment in the economic and social fields constitutes one of the fundamental objectives of all development efforts in the rural areas and it has emerged as an important issue in recent times. Microfinance is described as a powerful tool to improve economic development in a post-conflict context and to support post-conflict rehabilitation assistance. It is Sri Lanka's experience that attaining high levels of human development is a necessary precondition for creating greater

Corresponding author: Rathiranee Yogendrarajah, Department of Financial Management, Univerisity of Jaffna. E-mail: rathi.yogen@yahoo.com. opportunities for rural women.

Jaffna is considered one of the more prosperous districts in comparison with other districts in the North. However, poverty raised by inequalities in income, employment, infrastructure, health and educational facilities is trickled within the post-war situation. Prior to the explosion of the civil conflict, Jaffna enjoyed a healthy economy. The foreign aids are used to develop the local economy in Sri Lanka most probably in the war affected areas specifically in Jaffna because most of the displaced people who are female other than male staying here. This study deals with empowerment of rural women and the development of entrepreneurship through the micro credit programmes under post war development in selected rural areas in Jaffna District.

So far, 13 million micro entrepreneurs worldwide have benefited from micro loans to improve their 
income and boost their families out of poverty. But remain 200 million families who work hard, but cannot access affordable credit (Swider Paul, (2000).

According to Jan and Hayat (2011) microcredit schemes of Rural Support Programs (RSPs) are important for women economic empowerment. This helps to empower women socially and politically. Further, they have mentioned in their study the micro credit scheme of RSP in the area for has no doubt helped rural women in self employment generation and financially rewarding activities. Having an important contribution towards household's capital pool, women in the area became more recognized than before. Their role in family decision making, improved health and education of the family, and nourishing utilization indicated her equitable position in the family and in the society as well. The policy implication is that micro-credit programs for rural women should be strengthened both at the public as well as private level. This will lead not only empowering women socially, politically, and spiritually but also will contribute to poverty reduction at the national level.

\section{Research Problem}

Hamida, (2000), A case study from Tunisia' revealed that the women entrepreneurs face several obstacles to their desire for self employment, including difficult access to capital, low level of knowledge including literacy and numeracy skills, lack of training, inadequate market knowledge, for both purchases and sales, conservative traditions in their families and society at large, shyness and lack of public experience. Since ENDA's micro credit programme was launched in 1995, 1500 women have obtained loans from it. These loans have been used by them to gain emancipation and empowerment. Generating and controlling income is the starting point it enables women to learn to handling cash and, by running their micro enterprises, to learn how to handle the family budget and managing loan responsibility.
This leads to impress their perspective on family decision making and to take certain decisions alone. By gaining promotion through their own efforts and willingness to take risks, from home cleaner or factory worker to independent business individual and the micro entrepreneur gets position and independence. Literacy and numeracy, information and knowledge, participation in decision making, dignity, self confidence, independent travelling allows them to the personal empowerment. And it allows them to enhance their family, public and political empowerment too. It concluded that from their experience, the micro enterprise provides a path to women for empowering them, but that path is steep and has many drawbacks.

Okafor, Oluwakemi, \& Samuel, (2011) found from their study on 'Empowering women entrepreneurs in Ogun State through micro finance: Challenges and Prospects' that there is no significant relationship between the objectives of microfinance institutions and the financial needs of the respondents. This shows that although micro finance scheme is a good strategy for reduction of the poverty level of Nigerian women entrepreneurs, more awareness need to be created among Nigerian women entrepreneurs especially those in the rural areas. If much awareness will be created to enlighten the poor on the activities of microfinance, it has been identified as the best option for reduction of poverty, and a strategy for helping the poor and women entrepreneurs to access financial services. Helping women entrepreneurs with facilities to save and to have better access to credit will enable them manage risk, build assets, increase income, enjoy a better life and also help to reduce gender inequality among Nigerian entrepreneurs.

Ayadurai, (2004) concluded that the women entrepreneurs of the North East of Sri Lanka must be recognized as an important unit contributing to the economic growth of the country. They must be supported by the international organizations involved in the growth and development of entrepreneurship, 
especially women entrepreneurship, to help them "function" effectively as women entrepreneurs. Their constraints must be recognized and a structured and organized strategic plan put in place to help them overcome these limiting factors.

However, a little research has been undertaken to look beyond microfinance's economic benefits, at social mobilization, empowerment, stabilization, peace building and harmony, through social capital enhancement. Most of the authors investigated the developments and situation of the regions in their Reports and articles which were conducted by the aid of the NGOs and Other World nations. However most of the researches have been done regarding the women empowerment, entrepreneurship development and micro Credit programmes in worldwide it is very little bit in Sri Lanka especially in Jaffna District. This study attempt to fill this research gap and raising the following research question as a research problem:

"Does the Micro Credit Programme assist in developing women entrepreneurs in the rural areas?"

Objectives:

This study has the following objectives:

- To establish the linkage between Micro Credit and Women Entrepreneurship Development.

- To identify the impact of Micro Credit on Entrepreneurship Development.

- To suggest some possible solutions for improving the women empowerment and entrepreneurship development.

\section{Hypothesis}

The following assumptions have been made as hypothesis to prove it positively or negatively by concluding the research results.

$\mathrm{H}_{1}$ : "Higher the level of micro credit positively correlated with entrepreneurship development

$\mathrm{H}_{2}$ : "The micro credit has strong impact on women entrepreneurship development in the rural areas in Sri Lanka".

\section{Methodology}

\subsection{Sample}

Multi-stage random sampling technique was used in selecting women entrepreneurs. In the first stage, five Divisional Secretariat Divisions had been randomly selected in Jaffna. In the second stage of random sampling, two MFIs which are the beneficiaries from Samurthi Bank and Women rural development societies had been selected randomly for data collection purpose. The women entrepreneurs who lived in Kopay, Chavakachcheri, Varani and Kodikamam were selected in the third stage. In the fourth and final stage, the study randomly selected 16 members from each of the areas. In total, the study has collected information from 64 respondents out of 100 active entreprenurs in these areas. The women entrepreneurs who live in these areas have more than 2 years experience on their self employment activity and the members who obtained micro loan facilities from the Samurdhi Bank and WRDS have been selected.

\subsection{Data Collection}

Besides information on microcredit and entrepreneurship development, the survey collected detailed information on a variety of factors. For example, demographic information (age, sex, marital status, etc.) and socio-economic information (education, experience, savings, capital and economic empowerment) were collected for all entrepreneurs. Information relating to the amount of loan, repayment of loan, interest of loan also collected from them.

Primary and secondary data were used for the study. Primary data were collected from the questionnaire developed by the researcher and direct interview with the branch managers and field officers of Samurdhi Bank and Rural Development Officers of the DS Offices and secondary data were collected from the books, journal and other reports.

\subsection{Data Analysis}

The Pearson Correlation and Regression analysis 
statistical tools have been used to find out the linkage between Micro Credit and Entrepreneurship development and the impact of micro credit on entrepreneurship development respectively by using SPSS.

Regression analysis was carried out to test the impact of micro credit on entrepreneurship development. In this study the Micro credit is the independent variable and entrepreneurship development is the dependent variable. From these independent and dependent variables, the following relationship is formulated.

Entrepreneurship development is dependent upon the Micro Credit (M). It is represented as follows:

$$
E D=f(M)
$$

To test the impact of micro credit on entrepreneurship development the following equations can be formulated.

$$
\mathrm{ED}=\beta_{0+} \beta_{1}(\mathrm{M})
$$

Where $\beta_{0}$ and $\beta_{1}$ are the regression coefficient

$\mathrm{ED}=$ Entrepreneurship Development

$$
\mathrm{M}=\text { Micro credit }
$$

\section{Discussions and Findings}

From the data collected and analyzed with the help of Statistical Package for Social Sciences (SPSS) and it revealed the relationship between the micro credit and women Entrepreneurship and women empowerment in the Jaffna region is as follows:

Correlation test was made to examine the relationship between variables and results are tabulated. Table 1 show that there is a positive relationship between Micro credit and entrepreneurship development at 0.01 significant levels. From this result the hypothesis $\left(\mathrm{H}_{1}\right)$ has been proved clearly and there is strong relationship between micro credit and familial relations, personality factor and entrepreneurship development and moderate relationship between micro credit and financial liberation and socio economic status.

From the Table 2 the multiple regression analysis has been used to find out the influence of micro credit on entrepreneurship development. To meet the objective, the impact of the influencing factor of micro credit on entrepreneurship development has been investigated. The following model was used to investigate the relationship between micro credit and entrepreneurship development.

$$
\mathrm{Y}=\mathrm{a}+\beta_{1} \mathrm{X}_{1}+\varepsilon
$$

Where, $Y=$ Dependent Variable; (Entrepreneurship Development)

Intercept term $\beta_{1}$ are regression coefficients

$\mathrm{X}_{1}$ represent independent variables; (micro credit)

$$
\varepsilon=\text { Error term. }
$$

All the variables extracted could be explained 55\% of the variation in the entrepreneurship development through micro credit. The rest of $45 \%$ of the variation in the entrepreneurship is explained by other factors such as education, training and development, income of the activity, advising, monitoring, and other non-financial services etc.,

The estimated regression equation is as follows:

$$
\mathrm{Y}=4.604+1.656 \mathrm{X}_{1}
$$

\begin{tabular}{|c|c|c|c|c|c|c|}
\hline & $\mathrm{MC}$ & $\begin{array}{l}\text { Financial } \\
\text { Liberation }\end{array}$ & $\begin{array}{l}\text { Socio economic } \\
\text { status }\end{array}$ & $\begin{array}{l}\text { familial } \\
\text { relations }\end{array}$ & $\begin{array}{l}\text { personality } \\
\text { factor }\end{array}$ & $\begin{array}{l}\text { Entrepreneurshi } \\
\text { p Development }\end{array}$ \\
\hline MC & 1 & $.441 * *$ & $.488^{* *}$ & $.724 * *$ & $.689 * *$ & $.742 * *$ \\
\hline Financial Liberation & & 1 & .149 & $.407 * *$ & $.539 * *$ & $.440 * *$ \\
\hline Socio economic status & & & 1 & $.362 * *$ & $.452 * *$ & $.714^{* *}$ \\
\hline Savings & & & & 1 & $.831 * *$ & $.880 * *$ \\
\hline Economic Empowerment & & & & & 1 & $.914 * *$ \\
\hline Entrepreneurship development & & & & & & 1 \\
\hline
\end{tabular}

The significant $t$-value of each variable confirms the significant contribution of independent variable to the model.

Table 1

** Correlation is significant at the 0.01 level (2-tailed). 
Table 2

\begin{tabular}{lllll}
\hline \multicolumn{2}{l}{ Model Summary } & & \\
\hline Model & $\mathrm{R}$ & R Square & Adjusted R Square & Std. Error of the Estimate \\
1 & $.742^{\mathrm{a}}$ & .550 & .544 & 1.58677 \\
\hline
\end{tabular}

Predictors: (Constant), AVERMC

Table 3

\begin{tabular}{|c|c|c|c|c|c|c|}
\hline \multicolumn{7}{|c|}{ Coefficients $^{\mathrm{a}}$} \\
\hline \multirow[t]{2}{*}{ Model } & & \multicolumn{2}{|c|}{ Unstandardized Coefficients } & $\begin{array}{l}\text { Standardized } \\
\text { Coefficients }\end{array}$ & \multirow[t]{2}{*}{$\mathrm{t}$} & \multirow[t]{2}{*}{ Sig. } \\
\hline & & B & Std. Error & Beta & & \\
\hline \multirow{2}{*}{1} & (Constant) & 4.604 & .668 & & 6.889 & .000 \\
\hline & AVERMC & 1.656 & .172 & .742 & 9.643 & .000 \\
\hline
\end{tabular}

a. Dependent Variable: Entrepreneurship development

Table 4 ANOVA

\begin{tabular}{lllllll}
\hline Model & & Sum of Squares & df & Mean Square & F & Sig. \\
\hline \multirow{3}{*}{1} & Regression & 234.119 & 1 & 234.119 & 92.984 & $.000^{\mathrm{a}}$ \\
& Residual & 191.356 & 76 & 2.518 & & \\
\hline
\end{tabular}

a. Predictors: (Constant), AVERMC

b. Dependent Variable: Entrepreneurship development

The value of Beta coefficient is highest explaining that 74.2 percent of the variation in the entrepreneurship development can be explained by micro credit.

As illustrated by the table 4 it can be observed that there is no significant differences between micro credit and entrepreneurship development ( $\mathrm{p}$ value < 0.05 ) at 0.05 significant level. Table 4 revealed that the microcredit support the argument that the model is significant and can predict the outcomes. From this findings the hypothesis 2 has been proved as there is impact of micro credit on entrepreneurship development.

\section{Conclusions}

From the above discussion researcher can conclude that there is a positive relationship between micro credit and women empowerment. However, other factors such as training facilities, social awareness, advising regarding the usage of micro credit and other non-financial services, also have impact on women empowerment. The micro credit loan facilities for self-employment, is not enough in empowering poor women in rural areas because the other factors have strong impact on that.

Finally, it is concluded that micro credit is a tool for women entrepreneurship development. Further, Women need advice about how to utilize public, private, natural and other resources and services. Microcredit, thus, is not sufficient in empowering the women, but it is of the very important ingredients with the noncredit aspects in that process.

\section{Acknowledgment}

Author would like to thank to the Higher Education Twentieth Century (HETC) Project for providing financial support on this research publication. .

\section{References}

[1] ADB 1999, A study of NGOs, Sri Lanka. Asian Development Bank, URL:

[2] Aheeyar, M. 2006. Cash Grants and Micro-finance in livelihood recovery: experiences from tsunami-affected areas of Sri Lanka, HPG.

[3] Annual Report of the UN Economic and Social Commission for Asia and the Pacific 
[4] Annual Report of the UN Economic and Social Commission for Asia and the Pacific (ESCAP), 2007.

[5] Central Bank, 2004: Annual Report of Central Bank, Sri Lanka, 2004. Published by Central Bank Sri Lanka. URL: http://www.lanka.net/centralbank/AnnualReport2004.htm 1 (Last accessed on 31 Jan, 2006).

[6] Central Bank, 2004: Annual Report of Central Bank, Sri Lanka, 2004. Published by Central Bank Sri Lanka. URL: http://www.lanka.net/centralbank/AnnualReport2004.htm 1 (Last accessed on 31 Jan, 2006).

[7] Central Bank, 2004: Annual Report of Central Bank, Sri Lanka, 2004. Published by Central Bank Sri Lanka. URL: http://www.lanka.net/centralbank/AnnualReport2004.htm 1 (Last accessed on 31 Jan, 2006).

[8] CEPA. 2007. Absolute and Relative Consumption Poverty in Sri Lanka: evidence from the CFS2003-2004.

[9] Chowdhury, M.J.A., (2000), Microcredit, Enhancement of Entitlement, and Alleviation of Poverty: an Investigation into the Grameen Bank's Role in Bangladesh, Unpublished Ph.D. Dissertation, University of Stirling, Stirling, UK.

[10] Chowdhury, M.J.A., (2008), Does the Participation in the Microcredit Programs Contribute to the Development of Women Entrepreneurship at the Household Level? Experience from Bangladesh, Paper Presented at UNU-WIDER Workshop on Entrepreneurship and Economic Development, World Institute of Development Economics Research (WIDER), United Nations
University, Helsinki, Finland.

[11] David, M, J, R \& Liyanage, K. Harsha, 2005: Second generation problems at bridging digital divide in Sri Lanka: Practitioner's assessment. International Seminar on Bridging the Digital Divide: Best practices and false perceptions. Oxford Internet Institute. Oxford, UK. URL:

[12] Gerster, Richard, 2003: Independent Mid-term Assessment of Comprehensive Social http://www.adb.org/NGOs/docs/NGOSriLanka.pdf (Last accessed on 31 Jan, 2006).

[13] Sri Lanka Needs Micro finance to Empower Rural Micro Entrepreneurs for Sustainable Development Program of Sarvodaya.

URL:

http://www.gersterconsulting.ch/docs/CSDP.pdf (Last accessed on 31 Jan, 2006)

[14] Development September 27, 2010 by Microfinance Africa Leave a comment www.sundayobserver.lk, By Lalin Fernandopulle.

[15] World Bank, 'Women in 33 countries highly vulnerable to financial crisis effects - World Bank estimates increase in infant mortality, less girl education and reduced earnings', press release 6 March 2009.

[16] World Bank, 'World Bank calls for expanding economic opportunities for women as global economic crisis continues', press release 29 January 2009.

[17] World Economic Forum, 'Women's Empowerment: Measuring the Global Gender Gap', 2005. 